\title{
THE COPING STRATEGY OF THE SEAWEED FARMING WORKERS IN RANDUSANGA VILLAGE, BREBES
}

\author{
Rosdian Harmashinta Wahyu Arina \\ sintaarina1118@gmail.com \\ Gatot Sasongko \\ Yustinus Wahyudi \\ Satya Wacana Christian University \\ J1. Diponegoro No.52-60, Salatiga, Kec. Sidorejo, \\ Kota Salatiga, Jawa Tengah 50711
}

received: 19/11/18; revised: 12/3/19; published: 29/6/19

\begin{abstract}
The seaweed farming workers at Randusanga Wetan and Kulon village were facing a problem which also affecting their welfare, mainly their income. They could not decide their exact income because of their employment status, production and price instability. Coping strategy, which had been implemented, was one way to solve their problem as it made a connection and an active strategy. The form of 'connection'negotiated the portion of profit-sharing and enabled a household to borrow some money. Then, the active strategy was implemented by wild crab fishing, involving family member, intercropping with fish, working for 2-3 farmers, and utilizing 'sumpil'. This way, they could achieve a good welfare while at the same time, kept producing for their income.
\end{abstract}

Keywords: brebes; coping strategy; income coping strategy; seaweed

\section{INTRODUCTION}

As the largest archipelagic country with an area of about three-quarters of the total area, Indonesian waters have 27.2 percent of all flora and fauna species found in the world. It is not surprising that Indonesia is the country that has the second highest capture fisheries production in the world in marine waters, and has the seventh highest capture fisheries production in the world in public waters (FAO, 2016).

Besides the potential of capture fisheries, Indonesia's coastal areas also have the potential of marine aquaculture. Types of marine aquaculture commodities include seaweed, shrimp, and various types of fish such as grouper, snapper, milkfish and so on. During the period of 2011-2015, seaweed has become a leading commodity in the marine aquaculture and its production has increased to 17.37 percent every year (Table 1). Furthermore, Indonesia is the second largest country of aquaculture producer in the world, with a total production of 14.7 million tons worth of USD 10.56 billion. Indonesian aquaculture has grown at an average of $21 \%$ per year since 2000 , and is one of the 20 largest aquaculture producers in the world in 2014 (KKP, 2016).

The cultivation of tropical seaweed species from Kappaphycus alvarezii and Eucheuma spp. in Indonesia is such a major contributor to the growth of water plant production in the world. Indonesian seaweed cultivation production increases every year, where the increase is more than 10 times or less than one million tons in 2005 to 10 million tons in 2014. This increase will continue in line with the government policies to continue to increase seaweed cultivation production. Indonesia's contribution to the world from seaweed aquaculture production increased dramatically from 6.7 percent in 2005 to 36.9 percent in 2014 (FAO, 2016). From seaweed, Indonesia is able to produce 500 types of final products in all world industries, such as cosmetics, pharmaceuticals, food, to paper and biofuels.

The development of seaweed cultivation helped boosting the Indonesian economy. The Indonesian exports of seaweed and other algae throughout 2017 reached 174 thousand tons, an increase of $6.1 \%$ from 164 thousand tons previously. China is still the main destination for Indonesian seaweed exports. The data from the Central Bureau of Statistics (BPS, Badan Pusat Statistik) noted that the exports of seaweed and other algae to the Bamboo Curtain country in 2017 reached 149 thousand tons or 85.5 percent of total exports. This number increased $6.23 \%$ from the previous year.

Researches with a focus on seaweed as the object have been widely carried out by using a variety of analytical tools, spreading in various regions. The researches on 
seaweed cultivation using business analysis tools had been carried out by Asriany (2014), Putri et al. (2014), and Tutupary and Maatoke (2014). The results of these studies indicated that the seaweed commodities were feasible to be cultivated and developed and financially profitable. Researches on seaweed cultivation in terms of competitiveness had also been carried out by Fadli et al. (2018), Luhur et al. (2017), Mira et al. (2015). The result showed that the seaweed cultivation had a competitive and comparative advantage compared to another aquaculture. Researches on the development of seaweed cultivation were done by Putri et al. (2014), Tangko (2008), Suryawati and Erlina (2017), Deswati and Luhur (2014), Ningsih et al. (2016). None of these studies have seen farmers (farm workers) as a research object.

Workers, as the main research object that cultivates seaweed in the farms, are faced with uncertainties from the risk of employment status, production and price instability during the production process. The workers, in this case, have a risk of employment status because the worker's income does not come from working wages but it is based on the cooperation between the workers and farm owners. Thus, the workers have a risk because the income size depends on the harvest of the cultivated seaweed. With the cooperation model, the profit sharing system with the farm owners greatly influences the workers' income. The workers also experience a risk of production and price instability, which is such a link in the production process. It becomes a problem for the workers because of the production and price instability result in the uncertainties about their income. Out of the three factors, in the end, it creates such a pressure for the farm workers themselves, especially to fulfill the daily needs of the household and to survive. Therefore, one way that farm workers can use is by implementing a coping strategy.

Researches on coping strategy had been carried out by Utami et al. (2014), Suparman et al. (2008), Anggrayni et al. (2017), Mardy et al. (2018). They discussed various problems such as climate change and the diversification done by the community to meet their food needs. These researches are still open to conduct a research in terms of income or income coping strategies and not only limited to meeting food needs.

The income coping strategy has been investigated by several studies, namely Wasito et al. (2012), Astuti et al. (2015), and Oscar et al. (2018). These studies looked at the income coping strategies by farm workers, poor households, farmer households, tenant farmer households and urban farming households as the analysis units. There has been no research on income coping strategies related to farm workers, especially seaweed farm workers. In terms of the coping strategies, both income and food coping strategies can be done by using these three strategies, namely active, passive and networking strategy (Wasito et al., 2012; Astuti et al., 2015; Utami et al., 2014; Suparman et al., 2008; Anggrayni et al., 2017; Oscar et al., 2018).

Brebes Regency is one of the biggest centers of Gracilaria sp. in the waters of Java Island after the West Java. It can be seen from the farming area and the number of farmers. The cultivation location is in five sub-districts, namely Brebes, Bulakamba, Tanjung, Wanasari and Losari Districts. The largest producer and developer location is located in the Brebes District, mainly in the Randusanga Wetan and Kulon Village, located along the road to Randusanga Indah Beach. The land area of the farm reaches 1.190 ha and the type of the brackish water (fresh) is also suitable for planting seaweed.

The potential for seaweed farming cultivation produced in Brebes Regency shows a dynamic increase in the data, as shown in the news stating that from the total farming area of $12.748 \mathrm{ha}$, one third of the area (4.350 ha) is the area for seaweed cultivation (Afif, 2013). In addition to the farming area, the number of farmers which reached more than 400 people from 5 sub-districts in Brebes Regency made the production of seaweed and the variety of products produced from seaweed-based material increased in numbers. Since 2013, Gracilaria sp. even becomes the Brebes' leading commodity after red onion and salted eggs which have already become the leading commodities.

Based on the background and the problems raised, this study aims to look at the coping strategies carried out by the seaweed farming workers in a case study in Randusanga Wetan and Kulon Villages in facing the pressures from the risk of employment status, production uncertainty and price instability.

\section{METHOD}

This research was conducted using qualitative methods with a descriptive approach. The condition of the farm, daily activities of the farming workers and the seaweed production process were described and explored deeper. This research was conducted in the farming area in Randusanga Wetan and Kulon Village, Brebes District, Brebes Regency, Central Java Province.

The data collection was carried out by using three techniques, namely observation, interview and documentation study using a mobile phone and research note sheets. The observations were carried out by observing the behavior, individual or household activities at the research site directly and the researchers could be involved in various roles, both as non-participants and intact participants (Creswell, 2010). The interviews were conducted to key informants by directly asking open questions, so that the answers were obtained with in-depth information (in-depth interviews). The key informants in this study were farm workers who had employers and worked on ponds owned by farmer and did not have their own farms. Other sources of 
information were obtained from the farm owners and management of the "Gracilaria" farmer group. The data from the in-depth interviews were changed to transcripts to make it easier to categorize according to the theme similarity. After doing the categorization, a coding was done to organize the data which were related to one another. Based on the organized themes, it was then analyzed starting from the main theme of the research which was the coping strategy.

\section{RESULTS}

The seaweed farming cultivation in Brebes was originated from losses caused by the cultivation of milkfish and shrimp. Initially, Randusanga Village was once known as the largest shrimp producer in the 1980-1990 era. However, in 2000, the cultivation of milkfish and natural shrimp by farmers experienced a deterioration caused by several problems (Heryanto, 2015). For example, the time of harvesting milkfish which was relatively long, shrimps that were susceptible to viruses and especially when tidal water damaged the farms and flooded the village, thousands of milkfish and shrimp were frequently lost by coastal flood (Kustiasih, 2012; Afif, 2013). At some time, the farms were left empty without any activity. As a result, many farm workers experienced losses and were not able to generate income from the results of their work on the farmers' land.

In fact, after the occurrence of huge losses experienced, seaweed was increasingly becoming a top priority by farm workers to be cultivated. The reason was that seaweed cultivation was considered to be more profitable for farm workers for several reasons. First, seaweed would not be carried away by water when the tide was high because it was located floating near the bottom of the farm surface (Kustiasih, 2012). Moreover, the intercropping system produced mutualism symbiosis among each other, had a positive effect on the quality of the coastal environment because seaweed had a role as a biofilter and could significantly reduce the risk of white spot attack on shrimp farming (Yusuf, 2014; Mulatsih, 2015; Bappebti, 2016). In addition, seaweed could also be a regional leading commodity and improve the economy of the community (Asriany, 2014; Putri et al., 2014; Tutupary and Maatoke, 2014; Sugiyatno et al., 2013; Fadli et al., 2018), so that seaweed cultivation which initially only became a side job turned out to be the main job of the farm workers in Randusanga Village.

The cultivation of seaweed in farms by local residents simultaneously began in 2003-2004. It was the idea of some experts who had concerns about farming cultivation, namely Tabrani as chairman, Kusnandar and Budi Kurniawan as members (Parjiyono, 2013). The three were lecturers at the Faculty of Fisheries and Marine Sciences from Pancasakti University (UPS) Tegal. The idea was to test the transition of fish and shrimp farms to seaweed farms cultivation by distributing free Gracilaria sp. seaweed seeds to all farmers in Randusanga Wetan and Kulon Villages. In the end, the trials were carried out successfully and proceeded using the intercropping system. By using this system, the land productivity could be optimized properly. The Minister of Maritime Affairs and Fisheries, Mrs. Susi Pudjiastuti, in the 2015 Press Release, said that seaweed cultivation was beneficial because it was in accordance with the three pillars of development, namely Prosperity, Sustainability and Sovereignty, which are derivatives of the President of Indonesia's Vision and Mission (Nawa Cita).

In the process of producing Gracilaria sp. seaweed in Randusanga Village, the one who worked on it was not a farmer but a farm worker. 'Farmer' here had a different meaning from the general meaning of farmers. In general, 'farmers' referred to people who work in rice fields, fields and gardens, and were usually known as the owners and the workers of their own fields. Meanwhile, a 'farmer' in Randusanga Village referred to a person who owns the farm, and most of them do not work on their own farm. 'Farm workers' were those who work on the farm owned by farmers and usually they did not have their own farms. Here, the responsibility of the farm workers was greater than that the farmers', because they had to do all the production processes from the start until the products were ready for sale. The working time of the farm workers also run from morning to evening. Meanwhile, the farmer's responsibility was only as a foreman for his farm workers and implementing a profit-sharing as the work system between the farmers and the farm workers when the harvest time was over. The production process of the farm workers was also supported by the presence of the "Gracilaria" Farmers Group.

The development of seaweed production produced by the farm workers in Randusanga Village was quite volatile. The average production produced each year reached 500-700 tons. During the dry season, when the weather was good enough, the seaweed harvest could increase. The cold farm water conditions supported the growth of the seaweed and the drying process might only take 6-8 hours. In addition, the harvest could be carried out within half a month or 45 days . However, the amount of harvest could decrease during the rainy season. The main cause was that the seaweed did not get enough sunlight. As a result, the drying process could reach 7 days. Therefore, the seaweed might rot and damaged.

The applicable selling price of dry seaweed per $\mathrm{kg}$ in Randusanga Village followed the applicable price in the central market and it was fluctuative. The price fluctuations were influenced by the availability of seaweed stocks on the international market. When there were many seaweed stocks and many supplier countries in the international market, the selling price 
of seaweed per kg tended to decrease (Bappebti, 2016). The world seaweed prices affected the prices at the local level (Sukoco, 2016). Thus, farm workers could not determine their own prices and moreover, they could not determine the desired amount of income. It was also because the production of the farm workers in the "Gracilaria" farmer group was also distributed to big cities, such as Jakarta, at PT. Agarindo, Malang, Pacitan to Pasuruan.

As a main job, the farm workers spent most of their time in the farms owned by the farmers and carried out the production process from 6 a.m. to 5 p.m. The production process started from the initial stage, namely preparation stage. The only thing needed to be prepared is the Gracilaria sp. seaweed seeds and the farm condition which should be ready for planting the seaweed. The water condition which was clear and cold made a good initial growth of the seaweed .

Within two months, the seaweed could be harvested. A harvest period could be done for 7-15 days (depending on the number of the farm workers in a farm area). The farm workers harvested in the morning around $8 \mathrm{a} . \mathrm{m}$. by breaking down (gebur) and carrying simple equipment in the form of kandi, a 1.5 liter empty mineral water bottle that had been tied to the rope as a buoy. The harvested seaweed was then left to stand for 24 hours to remove the water contained in the grass.

The drying process - It took about 10 hours after being left for 24 hours. The farm workers dried the seaweed at $8 \mathrm{a} . \mathrm{m}$. and during the day, the farm workers turned the seaweed to dry evenly. The seaweed was arranged neatly on the waring sheets that had been prepared in advance on an open land and roadside.

After the drying process, the seaweed was then taken to be packaged using a $50 \mathrm{~kg}$ plastic roll (bagor) sack. The next process was to weigh them on the hanging scales and the weight of each seaweed sack could exceed the normal weight of $50 \mathrm{~kg}$ or less, depending on the way the farm workers putting in the seaweed. Finally, the farm workers must press each sack with a press. With two press tools available, the farm workers could press 1.5 tons of seaweed a day. When everything was neat, the seaweed was double-wrapped in the same sack and it was neatly sewn using raffia straps to make it easier for the farm workers to move them to a storage area next to the warehouse. The last three activities were carried out entirely in the "Gracilaria" Warehouse to be monitored by the person in charge.

The work system between the farmers and the farm workers was a profit-sharing system. The profitsharing system was obtained from each end of weighed seaweed harvest in the "Gracilaria" warehouse by the farm workers, then the money was given to the farmers for further distribution by a ratio of 60:40, where the percentage for the farm workers was smaller than the farmers'. The profit-sharing system here also emphasized that the responsibility was not fully owned by the farm workers, but the farmers were still responsible for all process. However, the farm workers, in this case, knew all the information about how to cultivate milkfish, natural shrimp and especially seaweed in the farmers' farms from the production process, starting by spreading the seeds to the harvesting stage.

The amount of dried seaweed per kg obtained by the farm workers in one harvest was then calculated to determine the amount of the income they earned. By using the normal price in the market which was $\mathrm{Rp} 4,500$, assuming that the production for 1 ha of a farm area in the two-month harvest period was an average of 3 tons of dried seaweed. The calculation was the total revenue $=$ quantity $\mathrm{x}$ price. Therefore, the revenue for two months was 3,000 $\mathrm{kg} \times \mathrm{Rp} 4,500=\mathrm{Rp}$ $13,500,000$ and the profit-sharing for farmers was $R p$ 2,500 , and their net income was $3,000 \mathrm{~kg} \mathrm{x} \mathrm{Rp} \mathrm{2,500}$ $=\operatorname{Rp~7,500,000.~While~the~profit-sharing~for~the~farm~}$ workers was Rp 2,000, and their net income was 3,000 $\operatorname{kg} \times \operatorname{Rp} 2,000=\operatorname{Rp~6,000,000~.~}$

The amount of dried seaweed per kg obtained by the farm workers in one harvest was then calculated to determine the amount of the income they earned. By using the normal price in the market which was $\mathrm{Rp} 4,500$, assuming that the production for 1 ha of a farm area in the two-month harvest period was an average of 3 tons of dried seaweed. The calculation was the total revenue $=$ quantity $\mathrm{x}$ price. Therefore, the revenue for two months was 3,000 $\mathrm{kg} \times \mathrm{Rp} 4,500=\mathrm{Rp}$ $13,500,000$ and the profit-sharing for farmers was $\mathrm{Rp}$ 2,500 , and their net income was $3,000 \mathrm{~kg} \times \mathrm{Rp} 2,500$ $=\mathrm{Rp} 7,500,000$. While the profit-sharing for the farm workers was Rp 2,000, and their net income was 3,000 $\operatorname{kg} \times \operatorname{Rp} 2,000=\operatorname{Rp} 6,000,000$.

The status of the seaweed farm workers in Randusanga Wetan and Kulon villages are as the ones who plant, harvest, dry, and pack the seaweed. The definition of farm workers here was different from the general meaning of hired laborers. The farm workers earned their income from how much dry seaweed they could produce every day in the farms owned by the farmers where they worked. While the hired laborers were those who worked and earned a fixed income in accordance with a daily or monthly count.

Their status as the farm workers required them to work harder than other hired laborers. Apart from the fact that their income could not be fixed, they were also very dependent on the results of the seaweed in the farms that could be harvested. With the status of a farm worker, the income depended on the work results. Sometimes, the farm workers got a lot of seaweed harvest, but the results could also be small. Thus, this would be different from the workers whose income was fixed and depended on the agreement with the place where they worked.

The farm workers generally received 40 percent of the total gross income that the farmer received as a result 
profit-sharing system. From this profit-sharing system, the farm workers could not determine the amount of income received. Meanwhile, they also had to divide their income into two parts, namely for the operational costs and the rest to fulfill their daily needs.

The proportion of the profit-sharing between the farm workers and the farmers also fluctuated. Sometimes, it increased and also decreased. The determining factor was the price of the seaweed and the agreements with the farmers. Therefore, the farm workers' life was very dependent on the work of the farmers as they were the ones providing their main jobs.

The number of the farm workers was ways bigger than the number of the farmers. This resulted in a competition between the seaweed farm workers to get employers. In general, the farm workers already had a frequent or permanent employer. This relationship had been formed not only because of economic factors, but also because of family factors. However, when there were crop failures for certain farmers, it resulted in the farm workers, who usually worked for these farmers, to look for other farmers. Therefore, this triggered a competition.

The farm workers could not get loans easily when their income was insufficient. The "Gracilaria" Farmers Group in Randusanga Wetan and Kulon Villages were often referred as a source of loans. However, loans could only be given to farmers with a certain amount of money on credit where the return came from the deductions for the next crop .

On the other hand, the farm workers could not get loans because they were considered at a high risk of bad credit. They could only get direct capital in the form of wet seaweed (seeds) for free from the Farmers Groups. It was hoped that the farm workers could work on the seeds they received to be planted in empty farms or a farmer.

The amount of seaweed in a single harvest depended on the natural conditions and the development of the seaweed itself. This was the main factor influencing the uncertainty of the seaweed production. Weather, high tides and the quality of seaweed determined the high and low seaweed production by the farm workers.

If the seaweed are going to be harvested, they must be observed first. It can be seen from the seaweed development, whether it is good or not. If the seaweed is good, it is ready to be harvested. If not, the harvest will be delayed.

A supportive weather, referred to when the seaweed got enough sunlight every day. That way, the seaweed quality was getting better because the jelly contained in the seaweed would increase. A good quality seaweed could also be obtained from natural conditions (both water and air around the farm) and through intercropping with milkfish and shrimp. When the water was clear water and the air was cool, the jelly would increase. If the amount of milkfish and shrimp was sufficient in one farm area, then the seaweed growth will also be good too.

On the other hand, the seaweed production below $50 \mathrm{~kg}$ was caused by the presence of competitive factors among other farm workers, such as rainy season, high tide and poor quality seaweed.

The large number of farm workers in a 1 ha farm area resulted in a competition among the farm workers. Usually, one farm area was 1 ha, and there were 2-3 farm workers. However, the fact showed that in a unit of a farm area was once harvested by $4-5$ farm workers. It indicated that the probability of getting as much seaweed as possible for themselves became even lower.

If the seaweed quality is bad, one farm can be harvested by many workers, reaching 4-5 people. This happened because the lives of the farm workers did depend on the seaweed. Therefore, even though the seaweed production was low and the income was decreased as they had to share with other farm workers, they kept doing it.

Rainy season could damage the seaweed quality. The rainy season reduced the sunlight frequency during the drying process. If the seaweed did not get enough sunlight, this would result in longer drying time. If the seaweed did not dry out immediately, then the seaweed would rot quickly. In the end, the results would be a little or even, it would result in a crop failure. As a result, the final scales of seaweed could be reduced to none at all.

Peteruhan, It was a term for a flash flood in Randusanga Wetan and Kulon Villages. Peteruhan was a condition where the high tide sea water in Randusanga Beach made the flash flood entered the farm area, residential housings and roads along the village. The peteruhan could damage the seaweed quality and often occured from the beginning of April to mid-July. The damage in the seaweed quality was caused by the entry of fresh water mixed with tidal sea water. This also risked a crop failure .

The harvest was once failed because of the last peteruhan in early February 2017. It was big because of a mix of fresh water. The farm in the south of the village was all destroyed and failed. There was a fact that the occurrence of the peteruhan often came at any time, making the seaweed production decreased and even a crop failure.

Based on the natural factors described earlier, the seaweed quality also determined whether the seaweed could be harvested by workers or not. If the seaweed quality was poor, the seaweed got rotten faster and turned white, so it could not be sold. Working by yourself does not generate a big result. Within a day, it can reach 50, then 63, and the next day can reach 60 . If it is unlucky, the seaweed was not good, and within a day, we can only get $40 \mathrm{~kg}$.

The seaweed quality affected the amount of seaweed shrinkage from wet to dry. A good quality seaweed 
shrinked up to 90 percent. For every a $50-\mathrm{kg}$-sugar sack containing wet seaweed, on average, it could produce $5 \mathrm{~kg}$ of dried seaweed with containing a lot of jelly. The workers could produce an average of 10 wet seaweed sacks of various weight (more than $50 \mathrm{~kg}$ ) because they were mixed with water and sumpil. The highest production of dried seaweed could reach $80 \mathrm{~kg}$ or more, which was equal to 16-17 wet seaweed sacks. However, when the quality of seaweed was poor, the shrinkage could reach 92-94 percent. That indicated that the weight of dried seaweed would drop to $4 \mathrm{~kg}$ or even $3 \mathrm{~kg}$ per sack. The dried seaweed produced from 10 wet seaweed sacks was only $40 \mathrm{~kg}$.

Of all the determinants of high and low seaweed production, the natural conditions and the development of seaweed were not easily predicted. Therefore, this became a production uncertainty for seaweed farm workers in Randusanga Wetan and Kulon Villages.

Price became the benchmark for the farmers and the farm workers to earn their income beside the production. However, the pricing was done by the markets where the sellers and buyers could not determine. Moreover, the farmers and the farm workers in Randusanga Wetan and Kulon Villages, where they were not the price makers, sellers and marketers. The development of the seaweed selling price can be seen in Figure 1, where the price per $\mathrm{kg}$ experiences a fairly fluctuative movement.

In 2008, the price of dried seaweed was $\mathrm{Rp} \mathrm{3,000/}$ $\mathrm{kg}$. This price was the starting price where the seaweed cultivation in the farms of Randusanga Village was began to be sought after by the farmers and the farm workers and the "Gracilaria" Farmer Group started to actively run. In 2009, the seaweed grass increased by 16.67 percent. This showed that the market began to develop. In 2010 to 2012, the price increased again up to 185 percent. The high price increase was due to the increase in Indonesian seaweed exports, aiming Germany, Hong Kong, Chile and Philippines (Sahat, 2013). The market expansion showed that there was a lot of demand for seaweed in Indonesia, especially Gracilaria sp. However, in 2013, the seaweed price decreased to 36.3 percent, and the price in 2014 was the lowest price for dried seaweed $/ \mathrm{kg}$. This decline occurred because the stock availability in the international market was still sufficient. Therefore, when Indonesia increased the supply while its demand was quite constant, it would affect the seaweed price at the local level. Then, in 2015-2016, the resale price increased 50 percent to Rp 4.500. The latest data in March 2017 showed that the prices increased slightly by 28 percent from $\mathrm{Rp}$ 4,500 to $\mathrm{Rp} 5,800$.

The fluctuations in the dried seaweed price affected the amount of profit-sharing between the farmers and the farm workers. It can be seen from Figure 2 that the proportion of profit-sharing for the farmers is more volatile than the farm workers'. When the price increases beyond the normal price, the farm workers can only get an average of $\mathrm{Rp} \mathrm{2,500} \mathrm{per} \mathrm{kg}$. However, when the price drops, the amount of profit-sharing received by the farm workers also decreases.

From Figure 2, the researchers conducted a simple calculation to show the percentage comparison of the profit-sharing between the farm workers and the farmers from the price of the dry seaweed $/ \mathrm{kg}$ which experienced fluctuations. In 2005, the normal price was Rp 4.500. In 2007 , the price was above normal reaching $\mathrm{Rp} 5,800$, and in 2014 , the price was below normal reaching Rp 3,000 . The whole calculation was using the assumption that the seaweed production by normal farm workers was $50 \mathrm{~kg} /$ day. The calculation results can be seen in Figure 3 .

Nominally, in the normal price in 2015 , the farm workers got a profit-sharing proportion of $\mathrm{Rp} 2,000 /$ $\mathrm{kg}$ of dried seaweed and they earned $\mathrm{Rp} 100,000$. The amount of money was sufficient to meet their operational costs and daily needs. In this case, the operational costs

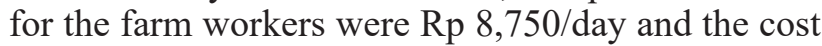
to meet their daily needs was $\mathrm{Rp} 80,000$. Especially in 2017, when the price was above normal, the profitsharing proportion for the farm workers reached $\mathrm{Rp}$ $2,500 / \mathrm{kg}$ of dried seaweed. The farm workers earned $\mathrm{Rp} 125,000$, and it was considered more than enough. However, in 2014 when the price was below normal, the profit-sharing proportion for the farm workers reached $R p 1,500$ and they only got $R p 75,000$. Here, the farm workers were considered unable to meet their operational costs, and it was not enough to meet their daily needs. This price was also the same as in 2008, where at that time, it was the initial price of cultivation in Randusanga Village. Yet, the difference was in the proportion of the results.

Based on Figure 4, by using the basis of normal prices in 2015-2016, it is seen that the movement of the proportion between the farmers and the farm workers is in the opposite direction. When the price of dry seaweed/kg changes from below normal in 2014 to normal prices in 2015-2016 or changes from normal prices to normal prices in 2017, the farmers' proportion seems to always increase. On the contrary, when the price changes above normal in 2017 to normal prices in 2015-2016 or a change from normal prices to below normal prices in 2014, the farm workers' proportion is increasing. Then, the proportion movement in 20102012 is different from the movement in 2014-2017 because the price of dried seaweed $/ \mathrm{kg}$ is above the normal price and does not change in level.

The proportion movement in the opposite direction became such a problem for the farm workers because the proportion of profit-sharing increased precisely when the price of dried seaweed $/ \mathrm{kg}$ decreased. While what was expected by the farm workers was that they could receive a high profit sharing proportion when the price of seaweed $/ \mathrm{kg}$ increased. In fact, the farm workers' life also depended on the price of the seaweed $/ \mathrm{kg}$ because 
it affected their income to meet their daily needs and operational costs for their main job.

\section{DISCUSSION}

According to Carver (1989), forms of coping strategies are differentiated into adaptive strategies and maladaptive coping strategies. The difference between the two lies in the problem solving. Adaptive coping, stressors can be dealt with or dealt with effectively, positively and make better contributions. The process of overcoming the problem is carried out by direct action as a gradual response effort. Specifically differentiated into adaptive strategies with active, passive coping and network use in the process of overcoming problem complexity.

Active strategy is a form of strategy that optimizes all the potential of the family to increase income because of the growing demands of life (Oscar, Mara, \& Nainggolan, 2018). Various forms of strategies that are built include: doing their own activities or doing a division of family work, looking for side jobs, and utilizing the potential of the forest to increase income. The passive strategy undertaken is a model of emphasis on subsistence patterns by prioritizing consumption needs rather than socio-economic needs. Emphasis or tightening of expenditure is a passive strategy, namely reducing family expenses (eg expenses for clothing, food, social costs, transportation, health, education, and other daily needs). In addition to carrying out active strategies and passive strategies, people also use kinship as a network to borrow money when economic needs are urgent while finance is no longer sufficient to meet the needs of their families. Borrowing money is one that is carried out by the community when there is an economic pressure such as the reduced income of farmers so that it is no longer sufficient to meet their daily needs. Borrowing money from neighbors is not based on the interest money system, but only with trust capital.

In dealing with the risks involved, farm workers use several strategies to keep meeting their needs and survive, including:

It was done by relying on trust, good relations and openness with the farmers as employers. This form could also be called as a social capital coping strategy. When the selling price of seaweed / $\mathrm{kg}$ fell, the profitsharing proportion between the farm workers and the farmers was 50:50. This determination was the result of negotiations between the farm workers, the farmers and Mr. Tabrani as the head of the "Gracilaria" Farmers Group who were also responsible for these problems. From this negotiation, it also indicated that in this cultivation business, it was not a business-oriented, but rather a family-oriented business.

In the end, there was a mutual cooperation between the farm workers and the farmers. The farm workers were benefitted because they had a cultural capital in the form of skills that could not be replaced by just anyone. Further, the farmers as the owners of the economic capital in the form of farms and seaweed could also maximize the existing resources by employing the farm workers.

In line with the capital theory, according to Pierre Bordieu (Adib, 2012), the ownership of habitus and good capital could influence the social realm of the society. The farm workers and the farmers in Randusanga Village also had their own habitus and capital. This made the activities in the social sphere (farm area) run well because of the existence of the good social capital.

With this kind of negotiation, the position in the work between the farm workers and the farmers became balanced. It indicated that it was different with other jobs where they differentiated the capital owner as the boss and the workers were only the subordinates. Also, with this kind of negotiation, the transactions between the farm workers and the farmers resulting in the profitsharing proportion became 50:50. It could be said that it was considered as a humane transaction in the farmers' economic morale based on the theory of James C. Scoot (Geertz, 1983). The patron-client bond that occured, where the farmers as the patrons and the farm workers as the clients, actually created the distribution of wealth. Both had a reciprocal relationship, where in fact, the farmers provided freedom to manage their seaweed farms for the farm workers with a humane profit-sharing. Therefore, the workers also gave their best as their responsibility.

This method was included in the form of coping strategies which were commonly carried out by individuals or households. However, what actually happened to the farm workers' households in Randusanga Village was different. When there was a farm worker's household who had a debt to other farm worker' households, the return was from the sincerity of each farm worker's household. Taking turns in borrowing some money also made them being not reluctant to help each other. The family relations with a high level of trust among the farm workers' household made the problem of financial difficulties to meet daily needs could be resolved properly.

Borrowing money from the neighbors was one way of coping with networking strategies carried out when they were under the pressure of the economic conditions. This finding was also similar to the researches by Wasito et al. (2012), Astuti et al. (2015), Utami et al. (2014) and Oscar et al. (2018). The difference was that Oscar et al (2018) found that debts were also made to institutions, cooperatives and moneylenders. The impact was that the trust in the fellow relatives was more oriented to the kinship and feelings of the brotherhood, while trust was formed with institutions based on profit principles.

The farm workers could get additional income when the harvested seaweed production was less and at one 
time unemployed. With a capital of Rp 10.000 for $1 \mathrm{~kg}$ of petek fishes as the food for natural crabs, the farm workers could fish freely on the farms owned by the farmers. With the selling price of natural crabs of $\mathrm{Rp}$ 80.000 - Rp 100.000 / kg, the farm workers who got more than $1 \mathrm{~kg}$ and were able to sell them, the money could cover a shortage of income for 1 day.

In an effort to increase their income, natural crab fishing activities carried out by the farm workers in the farmers' farms were in line with the coping strategies which were also found in other studies. Among them were Astuti et al (2015) who found the double income pattern as a side job to get additional income, Wasito et al (2012) who found additional work and livestock activities or additional income according to their expertise.

The purpose of the farm workers to involve their wives to help during the production process was to eliminate the possibility of asking for assistance to other farm workers. Therefore, they did not need to share their income with other farm workers from the profit-sharing with the farmers. In addition to shorten the time of work, the production results obtained would also be more.

When the farm workers were unemployed, it was common for the farmers to still ask for help from the farm workers to sell the milkfish and shrimp. Therefore, this could also become the additional income for the farm workers.

Based on the coping strategy in relation to this network, its social functioning could be seen from the family cooperation between the farm workers, the farmers and the "Gracilaria" Farmers Group in Randusanga Wetan and Kulon Villages. It was in line with Raharjo's (2015) thoughts on social functioning. He said that by coping strategy, it indicated that the individuals or households implement several ways to meet their needs and carry out their life's tasks.

In fact, most of the seaweed cultivation in Randusanga Village was now not intercropping with milkfish. Therefore, if the seaweed growth was not good or had a problem, then the intercropping was done. Its function was to avoid the existence of soil moss and klekap. This traditional way could easily clear the farm water, so that the seaweed growth was getting better.

When the amount of seaweed production produced by the farm workers was relatively low, this was the form of coping strategy which was carried out. Thus, it could cover the amount of seaweed production desired by the farm workers in one harvest time.

It was used by the farm workers to fix the farm barriers (dikes). The aim was to minimize the mixing of river water with sea water and maintain the salinity of the farm water. As a result, the seaweed quality was getting better, and the seaweed produced were more numerous and affecting the scales to be heavier.

Based on the coping strategy with an anticipation of the production processes by the farm workers, the view of Suharto (2002) has the same understanding as what happened to the farm workers in Randusanga Village. The point referred to the ability of the individuals or the households to utilize the existing resources. The simple farm workers' life led them to think creatively, using their abilities to overcome problems in their main job. In fact, they did not become a passive object who kept silent and surrendered to the situation.

The farmers' economic morale theory according to Scott (1983), it was stated that the nature of the farmers tended to avoid risk and it was in line with the form of coping strategy carried out by the farm workers in Randusanga village, where by anticipating the production process, it could reduce the risk of uncertainty in the production.

In the previous studies, the coping strategy was carried out with three strategies, namely active, passive and networking strategies (Wasito et al., 2012; Astuti et al., 2015; Utami et al., 2014; Suparman et al., 2008; Anggrayni et al., 2017; Oscar et al., 2018). The coping strategies done by the seaweed farm workers were limited only to two strategies, namely active and networking strategy. With these two strategies, the farm workers could maintain the living standards so that they did not carry out the passive strategy.

\section{CONCLUSION}

The coping strategies carried out by the farm workers in facing the risk problems at their main job were to use the networking and active strategies. From the overall coping strategies carried out by the farm workers, it appeared that the coping strategies could overcome not only one problem. It indicated that the coping strategy could be done by crossing. The form of the coping strategies carried out by the farm workers were included in the type of an adaptive coping with an active coping. This meant that there were direct and real actions from the farm workers in dealing with the complexity of the problem. The factors affecting the farm workers in the coping strategies could also be considered to have a positive effect. This showed that it made it easier for them to carry out the coping strategies.

\section{REFERENCES}

Adib, M., 2012. Agen dan Struktur dalam Pandangan Piere Bourdieu. Jurnal BioKultur, 1(2), pp.91-110. Afif, A. 2013. Harga Membaik, Petani Tambak Randusanga Mulai Tanam Rumput Laut Lagi. Retrieved from https://brebesnews.co/2013/08/ harga-membaik-petani-tambak-randusanga-mulaitanam-rumput-laut-lagi/

Anggrayni, F.M., Andrias, D.R. and Adriani, M., 2017. Ketahanan Pangan Dan Coping Strategy 
Rumah Tangga Urban Farming Pertanian Dan Perikanan Kota Surabaya. Media Gizi Indonesia, 10(2), pp.173-178.

Asriany, A., 2014. Analisis Usaha Tani Rumput Laut (Eucheuma Cattoni) Kecamatan Mandalle Kabupaten Pangkep. Jurnal Galung Tropika, 3(3), pp.132-138.

Astuti, T.W.H., 2015. Kajian Tekanan Ekonomi, Strategi Koping, Dan Kesejahteraan Keluarga Petani di Daerah Rawan Banjir (Doctoral dissertation, Tesis. Sekolah Pascasarjana. Bogor: Institut Pertanian Bogor).

Bappebti. 2016. Analisis bulanan periode desember 2015, 2015-2016.

Creswell, J.W., 2010. Research design pendekatan kualitatif, kuantitatif, dan mixed. Yogyakarta: Pustaka Pelajar.

Deswati, R.H. and Luhur, E.S., 2014. Profil Budidaya dan Kelembagaan Pemasaran Rumput Laut (Grasillaria Sp) di Kecamatan Muara Gembong, Kabupaten Bekasi, Jawa Barat. Buletin Ilmiah Marina Sosial Ekonomi Kelautan dan Perikanan, 9(1), pp.31-34.

Fadli, F., Pambudy, R. and Harianto, H., 2018. Analisis Daya Saing Agribisnis Rumput Laut di Kabupaten Lombok Timur. Jurnal Agribisnis Indonesia, 5(2), pp.111-124.

FAO. 2016. The State of World Fisheries and Aquaculture. https://doi.org/92-5-105177-1

Geertz, C., 1976. Involusi Pertanian: Proses Perubahan Ekologi Di Indonesia; Diterjemahkan Oleh S. Supomo. Bhratara.

Heryanto, T. 2015. Randusanga Kulon 1 Budidaya Rumput Laut. Pantura News. Retrieved from http:// www.panturanews.com/index.php/panturanews/ baca/12326/21/09/2015/randusanga-kulon-juara1-budidaya-rumput-laut

KKP. 2016. Kelautan dan Perikanan dalam Angka Tahun 2016.

Kustiasih, R. 2012. Rumput Laut, Harapan Baru Indramayu. Kompas.Com. Retrieved from http://bisniskeuangan.kompas.com/ read/2012/03/05/02584269/rumput.laut.harapan. baru.indramayu

Luhur, E.S., Witomo, C.M. and Firdaus, M., 2017. Analisa Daya Saing Rumput Laut Di Indonesia (Studi Kasus: Kabupaten Konawe Selatan, Sulawesi Tenggara). Jurnal Sosial Ekonomi Kelautan dan Perikanan, 7(1), pp.55-66.

Mardy, T., Uddin, M., Sarker, M., Roy, D. and Dunn, E., 2018. Assessing coping strategies in response to drought: A micro level study in the north-west region of Bangladesh. Climate, 6(2), p.23.

Mira, M., Triyanti, R. and Hikmayani, Y., 2015. Dinamika Daya Saing Usaha Rumput Laut. Jurnal Sosial Ekonomi Kelautan dan Perikanan, 10(2), pp.117-189.
Mulatsih, S., 2015. Model Optimasi Pengelolaan Kualitas Lingkungan melalui Peran Biofilter Rumput Laut (Gracilaria sp.) untuk Pengembangan Tambak yang Berkelanjutan. OSEATEK, 9(01).

Ningsih, R.W., Utami, P. and Dumasari, D., 2016. Potret Kewirausahaan Petani Pembudidaya Rumput Laut di Desa Randusanga Kulon Kec. Brebes Kab. Brebes. Agritech: Jurnal Fakultas Pertanian Universitas Muhammadiyah Purwokerto, 18(1).

Oscar, D., Mara, A. and Nainggolan, S., 2018. Analisis Hubungan Antara Coping Strategi Dengan Tingkat Pendapatan Petani Karet di Kecamatan Mestong Kabupaten Muaro Jambi. Journal of Agribusiness and Local Wisdom, 1(1), pp.38-47.

Parjiyono, Y. 2013. Unggulan UPS Tegal Produksi Rumput Laut Glacilaria Siap Go International. Retrieved October 14, 2016, from http://seaweed. undip.ac.id/unggulan-ups-tegal-produksi-rumputlaut-glacilaria-siap-go-international/

Putri, D., Dwi Sayekti, W., \& Rosanti, N. 2014. Analisis pendapatan dan strategi pengembangan budidaya rumput laut di Pulau Pahawang Kecamatan Punduh Pidada Kabupaten Pesawaran. Jiia, 2(1).

Raharjo, S. T. 2015. Isu-isu kontemporer: bidang praktek pekerjaan sosial, kesejahteraan sosial, profesi pekerjaan sosial. Bandung: UNPAD Press.

Sahat H.J. 2013. Rumput laut Indonesia. Warta Ekspor Kementerian Perdagangan RI, (September), 1-20. Diambil dari http://swa.co.id/business-strategy/ rumput-lautindonesia-rambah-eropa.

Scott, J. C. 1983. Moral Ekonomi Petani: Pergolakan dan Subsistensi di Asia Tenggara. Lembaga Penelitian, Pendidikan dan Penerangan Ekonomi dan Sosial.

Sugiyatno, S., Izzati, M. and Prihastanti, E., 2013. Manajemen Budidaya dan Pengolahan Pasca Panen Gracilaria verrucosa (Hudson) Papenfus. Study Kasus: Tambak Desa Mororejo, Kecamatan Kaliwungu, Kabupaten Kendal. Buletin Anatomi Dan Fisiologi, XXI(2), 42-50.

Suharto, E., 2002, December. Coping Strategies dan Keberfungsian Sosial: Mengembangkan Pendekatan Pekerjaan Sosial Dalam Mengkaji dan Menangani Kemiskinan. In Makalah yang disampaikan pada Seminar "Kemiskinan dan Keberfungsian Sosial: Merancang-Kembangkan Program Pembangunan Kesejahteraan Sosial yang Bernuansa Pekerjaan Sosial”. Institut Pertanian Bogor (IPB), Bogor (Vol. 17).

Sukoco. 2016. Harga Rumput Laut Kering Anjlok, Petani Pilih Jual Cepat Hasil Panen. Retrieved August 30, 2016, from http://regional.kompas. com/read/2016/04/26/08353801/Harga.Rumput. Laut.Kering.Anjlok.Petani.Pilih.Jual.Cepat.Hasil. Panen? utm_source $=n e w s \& u t m$ medium $=b p$ kompas\&utm_campaign $=$ related \&

Suparman, S., Pusparini, P., Aminah, M., Hardinsyah, H. 
and Tanziha, I., 2008. Strategi Koping Oleh Eumah Tangga Miskin Di Kabupaten Cirebon. Penelitian Gizi dan Makanan (The Journal of Nutrition and Food Research), 31(2).

Suryawati, S. H., \& Erlina, M. D. 2017. Strategi pengembangan usaha budidaya rumput laut di Kabupaten Buton Selatan. Jurnal Sosial Ekonomi Kelautan dan Perikanan, 12(1), pp.31-44.

Tangko, A. M. 2008. Budidaya Rumput Laut Di Provinsi Sulawesi Selatan. Media Akuakultur, 3(2), 137144. https://doi.org/http://dx.doi.org/10.15578/ ma.3.2.2008.137-144

Tutupary, O. F. W., \& Maatoke, C. D. 2014. Analisis Usaha Budidaya Rumput Laut di Desa Pediwang Kecamatan Kao Utara Kabupaten Halmahera Utara. UNIERA, 3(1).
Utami, B.W., Molo, M. and Widiyanti, E., 2014. Korelasi diversifikasi pendapatan dengan coping strategy pada rumah tangga petani penyewa lahan surutan di Wonogiri. Agriekonomika, 3(1), pp.21-33.

Wasito, Sumarwan, U., Sunarti, E., Dharmawan, A. H., \& Ananto, E. E. 2012. Strategi Coping dan Nafkah Serta Dampaknya terhadap Keberfungsian dan Ketahanan Fisik Keluarga Petani Miskin di Kabupaten Blora. Ipb. Insititut Pertanian Bogor. Retrieved from https://repository.ipb.ac.id/ handle/123456789/55412

Yusuf, M. 2014. Peningkatan Kualitas Rumput Laut Gracilaria Melalui Penerapan BMP di Sinjai. Retrieved October 14, 2016, from https://www.wwf. or.id/?36282/Peningkatan-Kualitas-Rumput-LautGracilaria-Melalui-Penerapan-BMP-di-Sinjai

Table 1. The Production of Marine Aquaculture in 2011-2015

\begin{tabular}{lrrrrr}
\hline \multicolumn{1}{c}{$\begin{array}{c}\text { Type of } \\
\text { Commodity }\end{array}$} & \multicolumn{5}{c}{ Year } \\
\cline { 2 - 6 } \multicolumn{1}{c}{2011} & \multicolumn{2}{c}{2012} & \multicolumn{1}{c}{2013} & \multicolumn{1}{c}{2015} \\
\hline Grouper & 8,091 & 8,786 & 11,024 & 11,369 & 137 \\
Snapper & 2,129 & 2,828 & 2,838 & 2,375 & 2,292 \\
Shrimp & 225 & 488 & 914 & 202 & 161 \\
Shells & 48,449 & 17,251 & 29,091 & 44,394 & 37,503 \\
Sea Cucumber & 219 & 475 & 206 & 138 & 22,029 \\
Seaweed & $4,539,413$ & $5,738,688$ & $8,335,663$ & $8,971,463$ & $10,112,107$ \\
Milkfish & 283 & 127 & 81 & 104 & 54 \\
Star Pomfret & - & - & 643 & 1,367 & 2,663 \\
Others & 7,019 & 1,094 & 5,811 & 2,833 & 2,978 \\
\hline Source: Statistics of Sea and Coasta Resource in 2017, BPS & & &
\end{tabular}

Source: Statistics of Sea and Coastal Resource in 2017, BPS

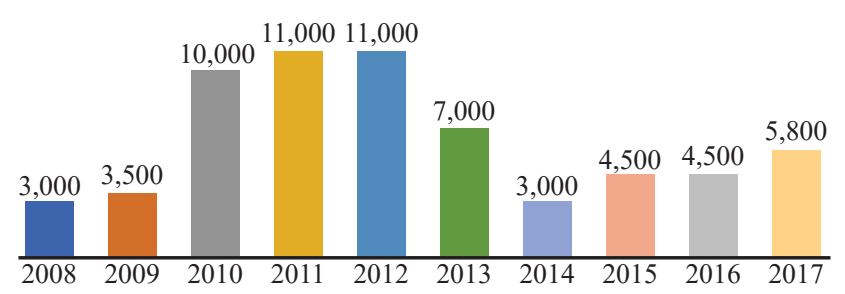

Source: Primary Data Processing, 2017

Figure 1. The Development of The Average Price of Dry Seaweed / Kg

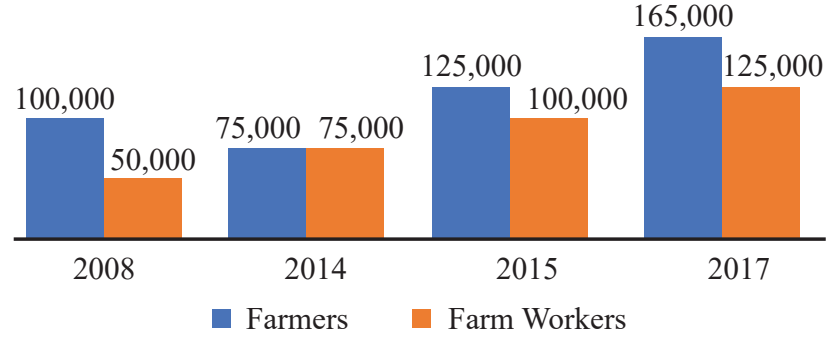

Source: Primary Data Processing, 2017

Figure 3. The Percentage Comparison of The Profit-Sharing for The Farm Workers and The Farmers 


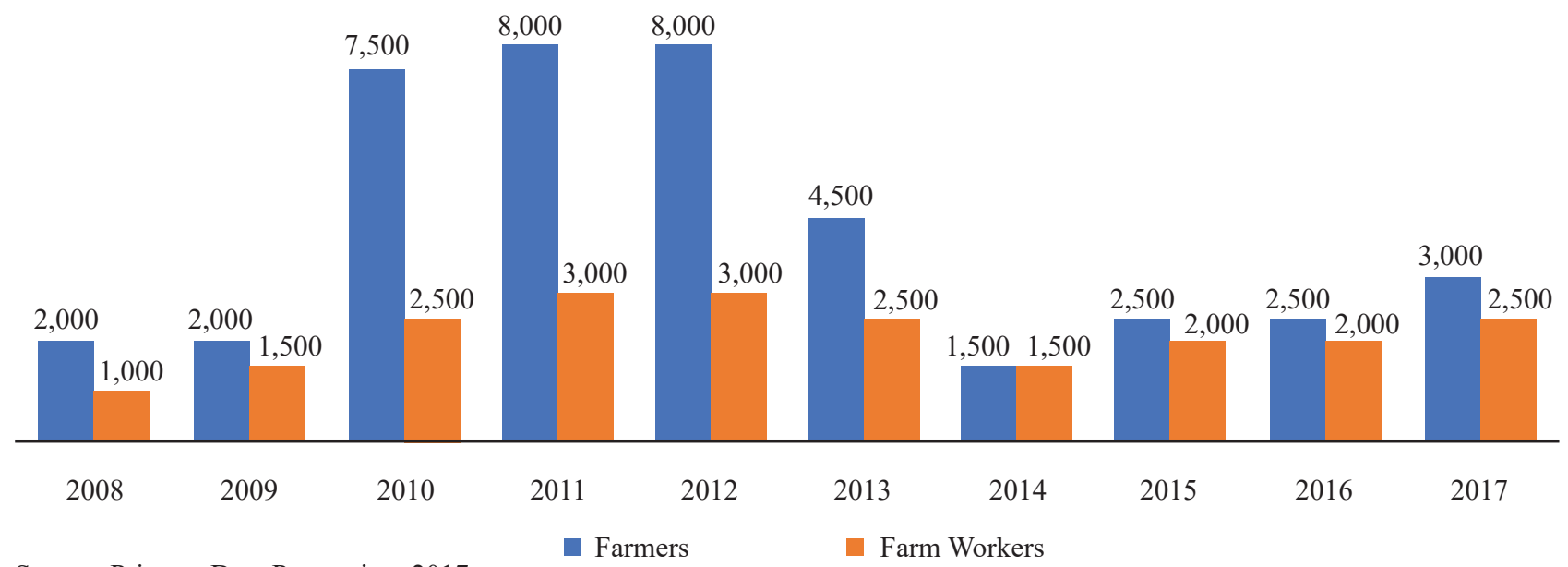

Source: Primary Data Processing, 2017

Figure 2. The Comparison of Profit-Sharing from The Development of The Average Price of Dry Seaweed (Rp)

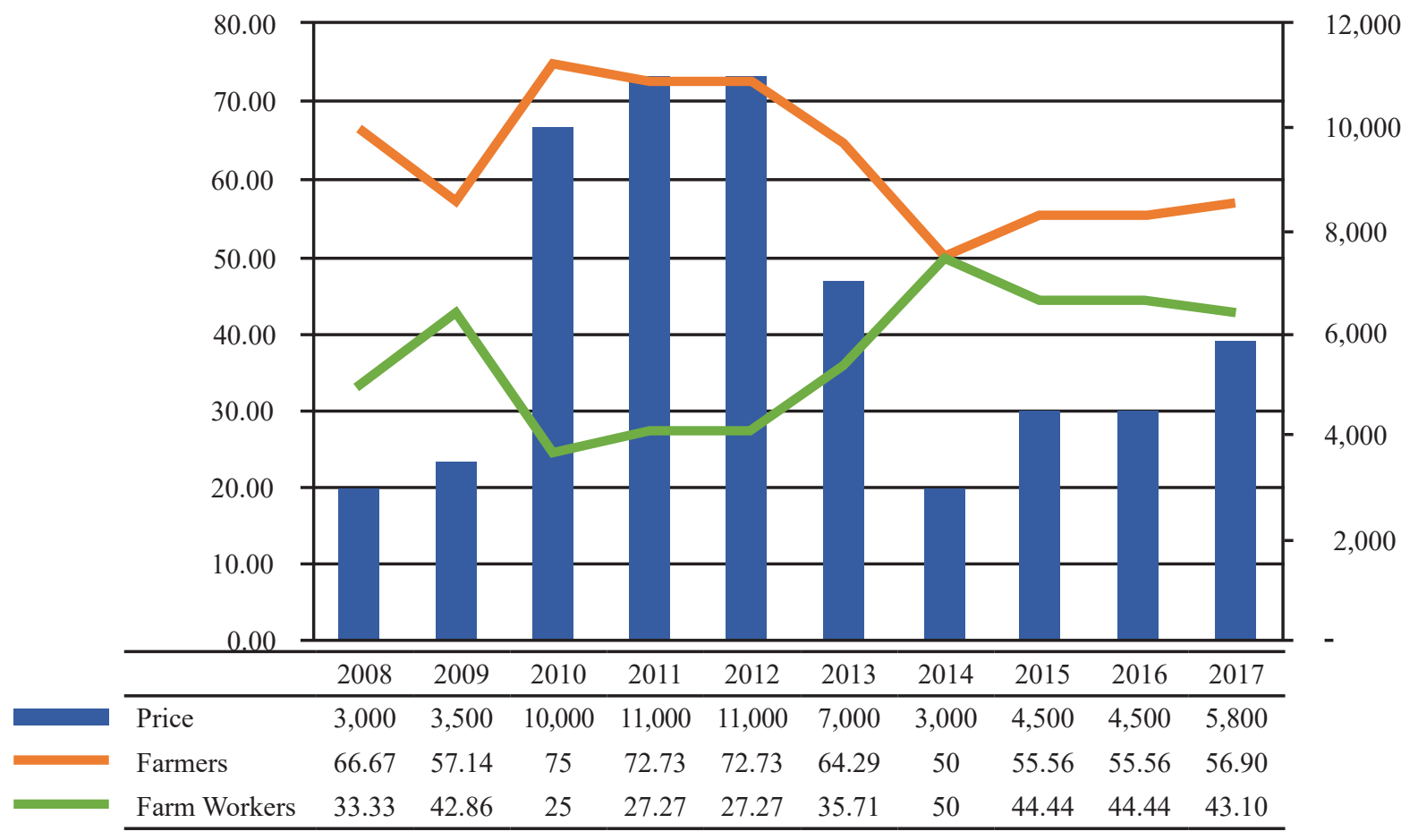

Figure 4. The Development of The Proportion of Profit-Sharing between The Farmers and Farm Workers (\%) 